\title{
RISIKO KEUANGAN DAN TINGKAT KESEHATAN KEUANGAN BANK DENGAN SIZE, INFLASI, DAN GDP SEBAGAI VARIABEL KONTROL PADA PERBANKAN SYARIAH DI INDONESIA
}

\author{
Yuwita Ariessa Pravasanti \\ STIE-AAS Surakarta \\ Email : yuwita.akuntansi@gmail.com
}

\begin{abstract}
This study aims to analyze the financial risk and health financial level of banks on Islamic banking in Indonesia. This study aims to get empirical evidence about the possibility of relationship and influence of financial risks (liquidity risk (Financing to Deposit Ratio), financing risks (Non Performing Financing) and operational risk (RWA for operational risk) and the financial soundness of banks (Net Operating margin, Return on Assets and Return on Equity) with the size of bank, inflation and Gross Domestic Product (GDP) as a control variable in islamic banking in Indonesia. This study used panel data analysis and used 9 islamic bank with 5 years in a period, from 2010 to 2014 so the sample used in this study were 45 data. The data were processed using Microsoft Excel and Eviews software version 8.

The results showed that simultaneously financial risk not significant effect on NOM, but significant effect on ROA and ROE. Partially NPF variables only significantly influence on NOM, FDR and NPF variable significant effect on ROA, and FDR variable significant effect on ROE. The control variables used in this study had no effect on health financial level.
\end{abstract}

Keywords: financial risk, Financing to Deposit Ratio (FDR), Non Performing Financing (NPF), ATMR for operational risk, health financial level of bank, Net Operating Margin (NOM), Return On Asset (ROA), Return On Equity (ROE)

\section{Pendahuluan}

Kegiatan usaha bank senantiasa dihadapkan pada risiko-risiko yang berkaitan erat dengan fungsinya sebagai lembaga intermediasi keuangan. Perkembangan lingkungan eksternal dan internal perbankan syariah yang semakin pesat mengakibatkan risiko kegiatan usaha perbankan syariah semakin kompleks. Bank dituntut untuk mampu beradaptasi dengan lingkungan melalui penerapan manajemen risiko yang sesuai dengan Prinsip Syariah. Penerapan manajemen risiko pada perbankan syariah disesuaikan dengan ukuran dan kompleksitas usaha serta kemampuan Bank. Oleh karena itu Bank Indonesia sebagai regulator perbankan di Indonesia pada tanggal 2 november 2011 mengeluarkan Peraturan Bank Indonesia JURNAL ILMIAH EKONOMI ISLAM VOL. 03 NO. 01, MARET 2017 nomor 13/23PBI/2011 mengenai Penerapan Manajemen Risiko Bagi Bank Umum Syariah dan Unit Usaha Syariah. Ini dimaksudkan supaya bank mampu mengidentifikasi masalah sejak dini, melakukan tindak lanjut perbaikan yang sesuai dan lebih cepat serta menerapkan good corporate governance dan manajemen risiko yang lebih baik, mengingat kinerja bank syariah di indonesia mengalami penurunan.

Tujuan dari penelitian ini adalah memberikan bukti empiris bahwa terdapat hubungan antara risiko keuangan dan tingkat kesehatan keuangan di perbankan syariah di Indonesia, serta memberikan bukti empiris bahwa terdapat perbedaan pengaruh yang signifikan dari setiap risiko keuangan terhadap tingkat kesehatan keuangan di 
perbankan syariah di Indonesia. Struktur dari artikel ini adalah sebagai berikut: pada bagian awal adalah tinjauan literatur studi, selanjutnya berkaitan dengan pertanyaan penelitian dan hipotesis, diikuti dengan penjelasan tentang metode penelitian dan pengumpulan data, pada bagian ketiga adalah hasil penelitian, dan pada bagian akhir adalah kesimpulan mengenai hasil penelitian.

\section{Tinjauan Pustaka}

Bank syariah atau bank Islam adalah bank yang beroperasi sesuai dengan ketentuan prinsip-prinsip syariah Islam (Tho'in, 2016: 164). Dengan kata lain, bank Islam adalah bank yang dalam operasionalnya mengikuti ketentuanketentuan syariah Islam, khususnya yang menyakut tata cara bermuamalat secara Islam (Perwata atmadja dan Antonio, 1992: 12).

Dalam beberapa tahun ini, terdapat beberapa penelitian yang berhubungan dengan risiko keuangan dan tingkat kesehatan keuangan pada perbankan syariah. Temuantemuan utama dari studi empiris sebelumnya yang berhubungan dengan risiko keuangan dan tingkat kesehatan keuangan perbankan mengalami perbedaan dalam hasilnya, untuk itu perlu dibuktikan dengan melakukan penelitian serupa.

Andreas Dietrich (2010) yang menganalisis determinan profitabilitas di Switzerland periode 1998-2008. Penelitian ini dilakukan dengan menganalisis faktor internal bank (CAR, BOPO, Bank Size, dan Biaya Dana) dan faktor eksternal bank (Tingkat Pajak dan Kapitalisasi pasar saham) terhadap ROE. Hasil penelitian menunjukkan bahwa BOPO berpengaruh signifikan negatif terhadap ROE. Muhimah (2010) yang menganalisis pengaruh Dana Pihak Ketiga (DPK), Capital Adequacy Ratio (CAR), Non
Performing Financing (NPF) Terhadap Jumlah Penyaluran Pembiayaan pada Bank Muamalat Indonesia. Penelitian ini berkesimpulan bahwa DPK dan NPF berpengaruh signifikan terhadap tingkat pembiayaan sedangkan NPF tidak berpengaruh terhadap Tingkat Pembiayaan.

Dr. Raj Bahadur Sharma dan Dr. K. Ravichandran (2011) yang menganalisis Faktor yang mempengaruhi profitabilitas bank konvensional dan bank syariah di UAE peride 2002-2010. Dari hasil penelitian diperoleh kesimpulan bahwasannya jumlah cabang, GDP per kapita, FIR, dan likuiditas berpengaruh terhadap profitabilitas bank konvensional, sedangkan jumlah cabang dan inflasi berpengaruh signifikan terhadap profitabilitas bank syariah.

Muhammad Akhtar, Khizer Ali, dan Shama Sadaqat (2011) yang menganalisis faktor yang mempengaruhi kinerja bank islam di pakistan periode 2006-2009. Penelitian ini menggunakan model regresi multivariat dengan hasil rasio pinjaman dan kecukupan modal berpengaruh signifikan terhadap profitabititas, sedangkan manajemen aset tidak berpengaruh terhadap profitabilitas. Imad Z. Ramadan, Qais A. Kilani, Thair A. Kaddumi (2011) yang meneliti sifat hubungan antara profitabilitas dan karakteristik faktor internal dan eksternal bank di Yordania. Hasil dari penelitian ini adalah profitabilitas cenderung terkait dengan kegiatan pinjaman yang tinggi, risiko kredit rendah, dan efisiensi biaya.

Suryani (2011) yang meneliti analisis pengaruh Financing To Deposit (FDR) terhadap Profitabilitas (ROA) Perbankan Syariah di Indonesia. Hasil dari penelitian ini adalah FDR tidak berpengaruh terhadap ROA. Nikos Ioani Schiniotakis (2012) yang melakukan penelitian Profitability Factors 
And Efficiency Of Greek Banks. Jenis Bank, laba Bersih Sebelum pajak, BOPO, Risiko Kredit, dan Tingkat Kecukupan Modal sebagai variabel independen dan ROA sebagai variabel dependen. Penelitian ini menyimpulkan bahwa Jenis Bank, Laba bersih sebelum pajak, risiko kredit, BOPO, dan tingkat kecukupan modal berpengaruh terhadap ROA.

Salman Ahmad, Et All (2012) yang meneliti Determinants of Profitability of Pakistani Banks: Panel Data Evidence For The Period 2001-2010. Penelitian ini menyimpulkan bahwa Biaya, Rasio Modal, dan CKP berpengaruh Signifikan negatif terhadap ROA. Abuzar M.A. Eljelly Ahmed Abdelgadir Elobeed (2013) yang meneliti Performance Indicators Of Banks In A Total Islamic Banking System: The Case Of Sudan. Variabel independen dalam penelitian ini adalah Rasio Likuiditas, Cakupan, cakupan Modal, Efisiensi, dan Kontrol. Hasil dari penelitian ini menyimpulkan bahwa keenam indikator memiliki hubungan yang signifikan terhadap kinerja.

Hussein A. Hassan (2015) yang meneliti Financial Risk And Islamic Banks' Performance In The Gulf Cooperation Council Countries. Variabel independen dalam penelitian ini adalah Risiko Kredit, Likuiditas, Risiko Modal, Risiko Operasional, sedangkan variabel dependennya adalah ROA dan ROE. Hasil penelitian ini menyimpulkan bahwa Risiko Modal dan Risiko Operasional berpengaruh negatif secara signifikan terhadap kinerja (ROA dan ROE).

Tyas Rafelia dan Moh. Didik Ardiyanto (2013) yang meneliti pengaruh CAR, FDR, NPF, BOPO terhadap ROE di Bank Syariah Mandiri periode 2008-2012. Hasil penelitian ini menunjukkan CAR tidak berpengaruh terhadap ROE, sedangkan FDR, NPF, dan BOPO berpengaruh terhadap ROE.

Nuha Fadhlurrahman dan Irni Yunita (2015) yang meneliti analisis pengaruh CAR, FDR, NPF dan NIM terhadap perubahan laba komprehensif di Bank Syariah periode 20122013. Hasil dari penelitian ini adalah CAR, FDR, NPF, dan NIM tidak berpengaruh signifikan secara parsial namun berpengaruh signifikan secara simultan.

\section{Metodologi Penelitian}

Penelitian ini bertujuan untuk mendapatkan bukti empiris mengenai risiko keuangan (risiko likuiditas yang diukur dengan FDR, risiko pembiayaan yang diukur dengan NPF, dan risiko operasional yang diukur dengan ATMR) dan tingkat kesehatan keuangan bank (Net Operating Margin, Return On Asset, dan Return On Equity) dengan variabel kontrol ukuran bank, inflasi, dan pertumbuhan Gross Domestic Product (GDP) pada perbankan syariah di Indonesia. Dengan demikian, terdapat enam hipotesis sebagai berikut:

H1: Risiko keuangan (risiko likuiditas, risiko pembiayaan, dan risiko operasional) berhubungan signifikan dengan tingkat kesehatan keuangan (NOM) pada perbankan syariah di Indonesia

H2: Risiko keuangan (risiko likuiditas, risiko pembiayaan, dan risiko operasional) berhubungan dengan tingkat kesehatan keuangan (ROA) pada perbankan syariah di Indonesia

H3: Risiko keuangan (risiko likuiditas, risiko pembiayaan, dan risiko operasional) berhubungan dengan tingkat kesehatan keuangan (ROE) pada perbankan syariah di Indonesia

H4: Risiko keuangan (risiko likuiditas, risiko pembiayaan, dan risiko operasional) 
berpengaruh signifikan dengan tingkat kesehatan keuangan (NOM) pada perbankan syariah di Indonesia

H5: Risiko keuangan (risiko likuiditas, risiko pembiayaan, dan risiko operasional) berpengaruh signifikan dengan tingkat kesehatan keuangan (ROA) pada perbankan syariah di Indonesia

H6: Risiko keuangan (risiko likuiditas, risiko pembiayaan, dan risiko operasional) berpengaruh signifikan dengan tingkat kesehatan keuangan (ROE) pada perbankan syariah di Indonesia

Dilihat dari Hipotesis pertama, kedua dan ketiga, maka dapat dikatakan bahwa jika menunjukkan hubungan positif, maka semakin tinggi risiko, semakin banyak keuntungan (tingkat kesehatan keuangan) dan sebaliknya. Namun, hubungan yang negatif dapat terjadi apabila risiko likuiditas meningkat, yang berarti bank tidak dapat memberikan pinjaman atau mengembalikan uang deposan, hal ini akan mempengaruhi pendapatan atau keuntungan (menurunnya tingkat kesehatan keuangan). Tujuan dari hipotesis keempat, kelima, dan keenam adalah untuk menguji seberapa besar pengaruh dan kepentingan relatif dari setiap jenis risiko keuangan.

Jenis penelitian ini adalah penelitian kausalitas dengan pendekatan kuantitatif. Penelitian kausalitas adalah desain penelitian yang disusun untuk meneliti kemungkinan adanya hubungan sebab akibat antar variabel (Sanusi, 2014:14). Menggunakan data sekunder yaitu laporan keuangan dari 9 Bank
Syariah yang ada di Indonesia dari tahun 2010- 2014. Sampel dalam penelitian ini ditentukan dengan menggunakan metode purposive sampling. Metode pengambilan sampel tersebut menggunakan kriteria sampel yang ditentukan oleh peneliti. Menurut dimensi waktunya, penelitian ini merupakan penelitian pooled yang merupakan gabungan dari times series yaitu penelitian yang menggunakan dimensi satu waktu dengan menggunakan beberapa objek penelitian (cross section). Variabel penelitian yang digunakan oleh peneliti dalam penelitian ini adalah:

1. Variabel dependen (Y), yaitu variabel yang nilainya dipengaruhi oleh variabel independen. Variabel dependen dalam penelitian ini adalah Net Operating Margin (NOM), Return On Asset (ROA), dan Return On Equity (ROE).

2. Variabel Independen (X), yaitu variabel yang menjadi sebab terjadinya atau terpengaruhinya variabel dependen. Variabel independen dalam penelitian ini adalah risiko keuangan yang dibedakan menjadi: risiko likuiditas (Financing Deposit Ratio-FDR), risiko pembiayaan (Non Performing Financing-NPF), dan risiko operasional (ATMR untuk risiko operasional).

3. Variabel kontrol, yaitu variabel yang menyebabkan hubungan variabel bebas dan terikat tetap konstan. variabel kontrol dalam penelitian ini adalah inflasi, ukuran bank, dan pertumbuhan GDP.

Tabel 1

Sampel Penelitian

\begin{tabular}{|c|c|c|c|c|c|}
\hline No & Nama Bank & $\begin{array}{c}\text { Tahun } \\
\text { Penelitian }\end{array}$ & No & Nama Bank & $\begin{array}{c}\text { Tahun } \\
\text { Penelitian }\end{array}$ \\
\hline 1 & BCA Syariah & $2010-2014$ & 6 & Muamalat & $2010-2014$ \\
\hline 2 & BNI Syariah & $2010-2014$ & 7 & Panin Syariah & $2010-2014$ \\
\hline 3 & BRI Syariah & $2010-2014$ & 8 & Bank Jawa Barat Syariah & $2010-2014$ \\
\hline 4 & Bukopin Syariah & $2010-2014$ & 9 & Mega Syariah & $2010-2014$ \\
\hline 5 & Mandiri Syariah & $2010-2014$ & & & \\
\hline
\end{tabular}


Tabel 2

Pengukuran Variabel

\begin{tabular}{|c|c|c|}
\hline No & Variabel & Penoukuran \\
\hline 1 & NOM & Net Operating Margin $=\frac{(P O-D B H)-B O}{\text { Rata2 } A P} \times 100 \%$ \\
\hline 2 & ROA & Return On Asset $=\frac{\text { Laba Sebelum Pajak }(\text { EBIT })}{\text { Rata }- \text { rata total Aset }} \times 100 \%$ \\
\hline 3 & ROE & Return On Equity $=\frac{\text { Earning After Tax }}{\text { Total Equity }} \times 100 \%$ \\
\hline 4 & FDR & $F D R=\frac{\text { Pembiayaan }}{\text { Dana Pihak Ketiga }} \times 100 \%$ \\
\hline 5 & NPF & $N P F=\frac{\text { Pembiayaan Bermasalah }}{\text { Total Pembiayaan }} \times 100 \%$ \\
\hline 6 & $\begin{array}{l}\text { ATMR untuk risiko } \\
\text { Operasinal }\end{array}$ & $\begin{array}{c}12,5 \times \text { beban modal Risiko Operasional ( } 15 \% \text { x rata-rata pendapatan bruto } 3 \\
\text { tahun terakhir) }\end{array}$ \\
\hline 7 & Inflasi & Tingkat Inflasi $=\frac{I H K_{t}-I H K_{t-1}}{I H K_{t-1}} \times 100 \%$ \\
\hline 8 & Ukuran Bank & Total Aktiva \\
\hline 9 & GDP & Pertumbuhan $G D P=\frac{G D P_{x}-G D P_{x-1}}{G D P_{x-1}} \times 100 \%$ \\
\hline
\end{tabular}

Data diolah dengan menggunakan software Microsoft Excel dan Eviews Versi 8, data diolah dengan metode data panel. Data panel menggabungkan jenis data cross section dan data time series. Menurut Gujarati (2006), analisis regresi data panel memiliki tiga macam model yaitu diantaranya Pooled Least Square, Fixed effect, dan Random Efect. Diantara ketiga uji data panel diatas, langkah selanjutnya adalah memilih uji data panel yang tepat untuk digunakan pada penelitian ini dengan melakukan pengujian Uji Chow (digunakan untuk memilih uji Pooled Least Square dengan uji Fixed effect Model) dan Uji Hausman (digunakan untuk memilih model Fixed Effect atau Random Effect).

\section{Hasil}

Hasil dari Uji Chow yang telah dilakukan dapat diketahui bahwa untuk model regresi NOM, ROA, dan ROE nilai probabilitas cross-section chi-square < 0,05 . Dengan nilai probabilitas tersebut, maka metode yang dipilih uji Chow adalah FEM (Fix Effect Model). Langkah selanjutnya adalah Uji Hausman. Hasil dari Uji Hausman diketahui bahwa untuk model regresi NOM, ROA, dan ROE menggambarkan nilai probabilitas cross section random effect $>0,05$. Dengan nilai probabilitas tersebut, maka metode yang dipilih adalah REM (Random Effect Model).

Tabel 3

Hasil Uji Korelasi

\begin{tabular}{|c|c|c|c|c|c|c|c|c|c|}
\hline & NOM & ROA & ROE & FDR & NPF & ATMR & SIZE & INFLASI & GDP \\
\hline NOM & 1.00 & 0.09 & 0.06 & -0.14 & -0.29 & -0.32 & -0.33 & -0.05 & 0.11 \\
\hline ROA & 0.09 & 1.00 & 0.75 & 0.48 & -0.27 & -0.02 & -0.01 & -0.23 & -0.10 \\
\hline ROE & 0.06 & 0.75 & 1.00 & 0.35 & -0.10 & 0.27 & 0.24 & -0.15 & 0.10 \\
\hline FDR & -0.14 & 0.48 & 0.35 & 1.00 & -0.17 & -0.11 & -0.07 & -0.15 & -0.09 \\
\hline NPF & -0.29 & -0.27 & -0.10 & -0.17 & 1.00 & 0.55 & 0.54 & 0.03 & -0.41 \\
\hline
\end{tabular}




\begin{tabular}{|c|c|c|r|r|r|r|r|r|r|}
\hline ATMR & -0.32 & -0.02 & 0.27 & -0.11 & 0.55 & 1.00 & 0.97 & -0.13 & -0.31 \\
\hline SIZE & -0.33 & -0.01 & 0.24 & -0.07 & 0.54 & 0.97 & 1.00 & -0.12 & -0.30 \\
\hline INFLASI & -0.05 & -0.23 & -0.15 & -0.15 & 0.03 & -0.13 & -0.12 & 1.00 & 0.26 \\
\hline GDP & 0.11 & -0.10 & 0.10 & -0.09 & -0.41 & -0.31 & -0.30 & 0.26 & 1.00 \\
\hline
\end{tabular}

Sumber : Hasil output Eviews 8 dan olahan Microsoft Excel 2016

Hubungan korelasi antar variabel dapat dilihat pada Tabel 3 yang menunjukkan bahwa variabel NOM memiliki hubungan negatif yang lemah dengan kedua variabel independen (FDR dan NPF) dan hubungan negatif yang sedang dengan ATMR untuk risiko operasional, sedangkan untuk variabel kontrol, NOM memiliki hubungan negatif yang lemah dengan ukuran bank, hubungan yang negatif sangat lemah dengan inflasi; dan memiliki hubungan positif yang lemah dengan GDP. Hal ini menunjukkan bahwa semakin kecil FDR, NPF, ATMR untuk risiko operasional, ukuran bank, dan inflasi, maka akan meningkatkan NOM. Berbanding terbalik dengan sebelumnya, apabila GDP meningkat, maka NOM juga akan meningkat.Widati (2012) menyebutkan bahwa bank memiliki kinerja yang baik apabila mampu menjaga keseimbangan antara pemeliharaan likuiditas yang cukup baik dengan pencapaian rentabilitas yang wajar serta pemenuhan modal yang memadai. Penelitian ini menguatkan penelitian yang dilakukan oleh Romdayanah (2011), Sherty Junita (2015), Taufik Ariyanto (2012), Neni (2008), dan Manurung (2014).

Variabel ROA memiliki hubungan negatif yang lemah dengan NPF, hubungan negatif yang sangat lemah dengan ATMR untuk risiko operasional, dan hubungan positif yang sedang dengan FDR. Untuk variabel kontrol, ROA memiliki hubungan negatif yang lemah dengan kedua variabel kontrol (inflasi, dan GDP) dan hubungan negatif yang sangat lemah dengan ukuran bank. Hal ini menunjukkan bahwa semakin kecil NPF, ATMR untuk risiko operasional, ukuran bank, inflasi, dan GDP maka akan meningkatkan ROA. Berbanding terbalik dengan sebelumnya, apabila FDR meningkat, maka ROA juga akan meningkat. Penelitian ini mendukung penelitian yang dilakukan oleh Husein et al (2015), Saira Javaid (2011), dan Burki and Niazi (2006).

Variabel ROE memiliki hubungan positif yang sedang dengan variabel independen FDR, hubungan positif yang lemah dengan ATMR untuk risiko operasional, dan memiliki hubungan negatif yang sangat lemah dengan variabel NPF. Untuk variabel kontrol, ROE memiliki hubungan positif yang sedang dengan ukuran bank, hubungan positif yang lemah dengan GDP; dan memiliki hubungan negatif yang lemah dengan Inflasi. Hal ini menunjukkan bahwa semakin kecil NPF dan inflasi, maka akan meningkatkan ROE. Berbanding terbalik dengan sebelumnya, apabila FDR, ATMR untuk risiko operasional, ukuran bank, dan GDP meningkat, maka ROE juga akan meningkat. Penelitian ini mendukung penelitian yang dilakukan oleh Husein et al (2015) yang menyatakan bahwa terdapat hubungan antara risko keuangan dengan kinerja yang diukur dengan ROE. 
Tabel 4

Hasil Uji Regresi NOM

\begin{tabular}{crrrr}
\hline \hline & & & & \\
Variable & Coefficient & Std. Error & t-Statistic & Prob. \\
\hline C & 1.676630 & 2.687571 & 0.623846 & 0.5365 \\
FDR? & -0.000390 & 0.002114 & -0.184551 & 0.8546 \\
NPF? & -0.073974 & 0.032611 & -2.268383 & 0.0291 \\
ATMR? & 0.355544 & 0.212824 & 1.670599 & 0.1030 \\
SIZE? & -0.380574 & 0.232869 & -1.634289 & 0.1105 \\
INFLASI? & -0.000281 & 0.000489 & -0.575017 & 0.5687 \\
GDP? & 0.042868 & 0.100546 & 0.426351 & 0.6723 \\
\hline \hline & Weighted Statistics & & 0.071665 \\
R-squared & 0.208022 & Mean dependent var & \\
Adjusted R-squared & 0.082973 & S.D. dependent var & & 0.240218 \\
S.E. of regression & 0.230036 & Sum squared resid & & 1.010837 \\
F-statistic & 1.663525 & Durbin-Watson stat & & \\
Prob(F-statistic) & 0.156774 & & \\
\hline \hline
\end{tabular}

Sumber : Hasil output Eviews 8 dan olahan Microsoft Excel 2016

Pada tabel 4 diperoleh persamaan regresi data panel sebagai berikut:

$$
\begin{aligned}
\text { NOM } & : 1,676630-0,000390 \text { FDR - } \\
& 0,073974 \text { NPF }+0,355544 \text { ATMR } \\
& \text { Untuk Risiko Operasional - } \\
& 0,380574 \text { SIZE }-0,000281 \\
& \text { INFLASI + 0,042868 GDP }
\end{aligned}
$$

Model regresi diatas dapat dijelaskan bahwa apabila variabel variabel independen (Financing to Deposit Ratio, Non Performing Financing, ATMR untuk risiko operasional ) serta variabel kontrol (ukuran bank, inflasi, dan Gross Domestic Product) dianggap konstan, maka meningkatkan NOM sebesar $1,6766 \%$. Koefisien regresi variabel FDR diperoleh nilai sebesar 0,000390, artinya apabila terjadi penurunan FDR sebesar 1\%, maka meningkatkan NOM sebesar 0,000390\%.
Koefisien regresi variabel NPF diperoleh nilai sebesar 0,073974, artinya apabila terjadi penurunan NPF sebesar $1 \%$, maka meningkatkan NOM sebesar 0,073974\%. Koefisien regresi variabel ATMR untuk risiko operasional diperoleh nilai sebesar 0,355544, artinya apabila terjadi kenaikan atau peningkatan ATMR untuk risiko operasional sebesar $1 \%$, maka meningkatkan NOM sebesar 0,355544\%.

Pengaruh variabel Financing to Deposit Ratio, Non Performing Financing, dan ATMR untuk risiko operasional terhadap variabel NOM sebesar 0,082973. Hal ini menunjukkan bahwa persentase sumbangan pengaruh variabel Financing to Deposit Ratio, Non Performing Financing, dan ATMR untuk risiko operasional terhadap variabel NOM hanya mampu dijelaskan sebesar 8,30 persen, sedangkan 
sisanya sebesar 91,70 persen dipengaruhioleh faktor lain. Hasil Uji t diketahui bahwa variabel bebas Financing to Deposit Ratio (FDR) berpengaruh tidak signifikan pada pada Net Operating Margin (NOM) karena nilai $\mathrm{t}$ sebesar 0,184551 dan $(\mathrm{p}=0,8548>0,05)$, Non Performing Financing (NPF) berpengaruh signifikan pada Net Operating Margin (NOM) karena nilai t sebesar 2,268383 dan ( $\mathrm{p}=0,0291<0,05)$, dan ATMR untuk risiko operasional berpengaruh tidak signifikan pada pada Net Operating Margin (NOM) karena nilai $\mathrm{t}$ sebesar 1,670599 dan $(\mathrm{p}=0,1030>0,05)$.

Hasil dari uji $F$ pada tabel 4 , uji $F$ hitung sebesar 1,663525 dengan nilai signifikasi $\mathrm{P}=0,156774>0.05$ sehingga dapat dikatakan bahwa Financing to Deposit Ratio (FDR), Non Performing Financing (NPF), ATMR untuk risiko operasional, ukuran bank, inflasi, dan Gross Domestic Product (GDP) secara bersama - sama tidak berpengaruh terhadap Net Operating Margin (NOM). Pembiayaan yang disalurkan oleh bank dengan menggunakan dana pihak ketiga dinilai kurang lancar, sehingga menurunkan kualitas dari nilai pembiayaan, dan tidak berdampak langsung terhadap margin yang diperoleh bank. Penelitian ini menguatkan penelitian yang dilakukan oleh Elisa Puspitasari (2014), namun tidak konsisten dengan penelitian yang dilakukan oleh sidabalok dan viverita (2010).

Pada tabel 5 diperoleh persamaan regresi data panel sebagai berikut:

ROA: $-15,2140199646+0,135496678557$ $F D R-1,22031325267 N P F+$ 0,661890318379 ATMR Untuk Risiko Operasional $0,0300046919898 \quad$ SIZE 0,00879548818711 INFLASI 1,46192048962 GDP

Model regresi diatas dapat dijelaskan bahwa apabila variabel variabel independen (Financing to Deposit Ratio, Non Performing Financing, ATMR untuk risiko operasional ) serta variabel kontrol (ukuran bank, inflasi, dan Gross Domestic Product) dianggap konstan, maka meningkatkan ROA sebesar 15,2140\%. Koefisien regresi variabel FDR diperoleh nilai sebesar 0,135497, artinya apabila terjadi peningkatan FDR sebesar 1\%, maka meningkatkan ROA sebesar 0,135497\%.

Tabel 5

Hasil Uji Regresi ROA

\begin{tabular}{crrrr}
\hline \hline Variable & Coefficient & Std. Error & t-Statistic & Prob. \\
\hline \hline C & -15.21402 & 20.19513 & -0.753351 & 0.4559 \\
FDR? & 0.135497 & 0.034760 & 3.898103 & 0.0004 \\
NPF? & -1.220313 & 0.495686 & -2.461869 & 0.0185 \\
ATMR? & 0.661890 & 1.891229 & 0.349979 & 0.7283 \\
SIZE? & -0.030005 & 2.068121 & -0.014508 & 0.9885 \\
INFLASI? & -0.008795 & 0.009053 & -0.971580 & 0.3374 \\
GDP? & -1.461920 & 1.440955 & -1.014550 & 0.3167 \\
& Weighted Statistics & & \\
\hline \hline R-squared & 0.319296 & Mean dependent var & 2.037867 \\
Adjusted R-squared & 0.211817 & S.D. dependent var & 5.951144 \\
S.E. of regression & 5.283407 & Sum squared resid & 1060.747
\end{tabular}




\begin{tabular}{llll} 
F-statistic & 2.970766 & Durbin-Watson stat & 1.236494 \\
Prob(F-statistic) & 0.017718 & & \\
\hline \hline & Unweighted & Statistics & \\
\hline \hline R-squared & 0.319296 & Mean dependent var & 2.037867 \\
Sum squared resid & 1060.747 & Durbin-Watson stat & 1.236494 \\
\hline \hline
\end{tabular}

Sumber : Hasil output Eviews 8 dan olahan Microsoft Excel 2016

Koefisien regresi variabel NPF diperoleh nilai sebesar 1,22031325267, artinya apabila terjadi penurunan NPF sebesar $1 \%$, maka meningkatkan ROA sebesar 1,2203\%. Koefisien regresi variabel ATMR untuk risiko operasional diperoleh nilai sebesar 0,661890318379, artinya apabila terjadi kenaikan atau peningkatan ATMR untuk risiko operasional sebesar $1 \%$, maka meningkatkan ROA sebesar 0,6619\%.

Pengaruh variabel Financing to Deposit Ratio, Non Performing Financing, dan ATMR untuk risiko operasional terhadap variabel ROA sebesar 0,211817. Hal ini menunjukkan bahwa persentase sumbangan pengaruh variabel Financing to Deposit Ratio, Non Performing Financing, dan ATMR untuk risiko operasional terhadap variabel ROA hanya mampu dijelaskan sebesar 21,18 persen, sedangkan sisanya sebesar 78,82 persen dipengaruhi oleh faktor lain.

Variabel bebas Financing to Deposit Ratio (FDR) berpengaruh signifikan pada pada Return On Asset (ROA) karena nilai t sebesar 3,898103 dan ( $\mathrm{p}=0,0004<0,05)$, Non Performing Financing (NPF) berpengaruh signifikan pada Return On Asset (ROA) karena nilai $\mathrm{t}$ sebesar 2,461869 dan $(\mathrm{p}=0,0185<0,05)$, dan ATMR untuk risiko operasional berpengaruh tidak signifikan pada pada Return On Asset (ROA) karena nilai t sebesar 0,349979 dan $(\mathrm{p}=0,7283>0,05)$.
Hasil dari uji $\mathrm{F}$ pada tabel 4.11, uji $\mathrm{F}$ hitung sebesar 2,970766 dengan nilai signifikasi $\mathrm{P}=0,017718<0.05$ sehingga dapat dikatakan bahwa Financing to Deposit Ratio (FDR), Non Performing Financing (NPF), ATMR untuk risiko operasional, ukuran bank, inflasi, dan Gross Domestic Product (GDP) secara bersama - sama berpengaruh signifikan terhadap Return On Asset (ROA).

Hal yang sama juga ditunjukkan oleh penelitian Puji Astutik (2015), Bakti S.R (2014) dan Edy Satrio Wibowo (2013) yang menerangkan bahwa FDR berpengaruh signifikan terhadap ROA, sedangkan NPF tidak berpengaruh signifikan terhadap ROA. Hal ini dapat dilihat dari nilai NPF yang relative rendah memungkinkan bahwa kredit macet di bank syariah juga rendah. Adanya kredit bermasalah akan menyebabkan kredit yang disalurkan tidak memberikan kontribusi yang baik. Penelitian ini juga didukung oleh Suyono (2005) dan Ponco (2008). Penelitian ini juga menguatkan penelitian Adi Setyawan (2009) dan Supriyanti (2009) yang menguji tingkat kesehatan keuangan bank umum konvensional dan bank umum syariah. Hasilnya menunjukkan pada bank Financing to Deposit Ratio (FDR) berpengaruh positif dan signifikan terhadap Return on Asset (ROA). Untuk variabel kontrol (Ukuran bank, inflasi dan GDP) berpengaruh tidak signifikan terhadap ROA. 
Pada tabel 6 diperoleh persamaan regresi data panel sebagai berikut:

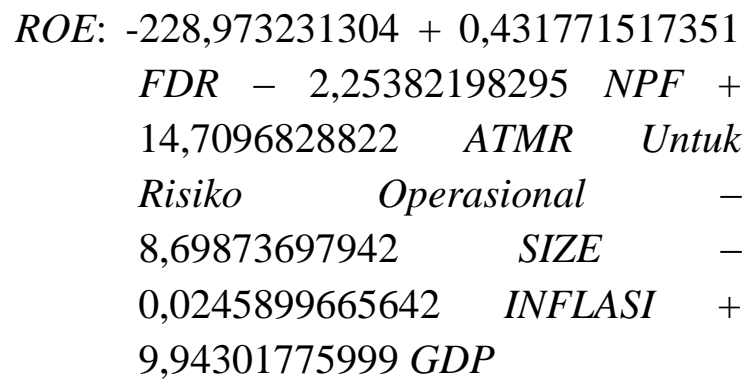

Berdasarkan model regresi di atas dapat dijelaskan bahwa apabila variabel variabel independen (Financing to Deposit Ratio, Non Performing Financing, ATMR untuk risiko operasional ) serta variabel kontrol (ukuran bank, inflasi, dan Gross Domestic Product) dianggap konstan, maka meningkatkan ROE sebesar $228,9732 \%$. Koefisien regresi variabel FDR diperoleh nilai sebesar 0,43177, artinya apabila terjadi penurunan FDR sebesar $1 \%$, maka meningkatkan $\mathrm{ROE}$ sebesar $0,43177 \%$.

Tabel 6

Hasil Uji Regresi ROE

\begin{tabular}{crrrr}
\hline \hline Variable & Coefficient & Std. Error & t-Statistic & Prob. \\
\hline \hline C & -228.9732 & 87.30581 & -2.622657 & 0.0125 \\
FDR? & 0.431772 & 0.134664 & 3.206291 & 0.0027 \\
NPF? & -2.253822 & 1.973071 & -1.142291 & 0.2605 \\
ATMR? & 14.70968 & 8.172594 & 1.799879 & 0.0798 \\
SIZE? & -8.698737 & 8.950020 & -0.971924 & 0.3372 \\
INFLASI? & -0.024590 & 0.034148 & -0.720096 & 0.4759 \\
GDP? & 9.943018 & 5.552397 & 1.790761 & 0.0813 \\
\hline \hline & Weighted Statistics & & \\
\hline \hline R-squared & 0.328857 & Mean dependent var & 9.349395 \\
Adjusted R-squared & 0.222887 & S.D. dependent var & 19.21872 \\
S.E. of regression & 16.94207 & Sum squared resid & 10907.28 \\
F-statistic & 3.103308 & Durbin-Watson stat & 1.938851 \\
Prob(F-statistic) & 0.014239 & & \\
\hline \hline
\end{tabular}

Sumber : Hasil output Eviews 8 dan olahan Microsoft Excel 2016

Koefisien regresi variabel NPF diperoleh nilai sebesar 2,25382198295, artinya apabila terjadi penurunan NPF sebesar 1\%, maka meningkatkan ROE sebesar 2,2538\%. Koefisien regresi variabel ATMR untuk risiko operasional diperoleh nilai sebesar 14,7096828822, artinya apabila terjadi kenaikan atau peningkatan ATMR untuk risiko operasional sebesar $1 \%$, maka meningkatkan ROE sebesar 14,7097\%.
Pengaruh variabel Financing to Deposit Ratio, Non Performing Financing, dan ATMR untuk risiko operasional terhadap variabel ROE sebesar 0,222887. Hal ini menunjukkan bahwa persentase sumbangan pengaruh variabel Financing to Deposit Ratio, Non Performing Financing, dan ATMR untuk risiko operasional terhadap variabel ROE hanya mampu dijelaskan sebesar persen, sedangkan 
sisanya sebesar 77,71 persen dipengaruhi oleh faktor lain.

Variabel bebas Financing to Deposit Ratio (FDR) berpengaruh signifikan pada pada Return On Equity (ROE) karena nilai t sebesar 3,206291 dan ( $\mathrm{p}=0,0027<0,05)$, Non Performing Financing (NPF) berpengaruh tidak signifikan pada Return On Equity (ROE) karena nilai t sebesar 1,142291 dan $(\mathrm{p}=0,2605>0,05)$, dan ATMR untuk risiko operasional berpengaruh tidak signifikan pada pada Return On Equity (ROE) karena nilai t sebesar 1,799879 dan ( $\mathrm{p}=0,0798>0,05)$.

Hasil uji $\mathrm{F}$ pada tabel 6 , uji $\mathrm{F}$ hitung sebesar 3,103308 dengan nilai signifikasi $\mathrm{P}$ $=0,014239<0.05$ sehingga dapat dikatakan bahwa Financing to Deposit Ratio (FDR), Non Performing Financing (NPF), ATMR untuk risiko operasional, ukuran bank, inflasi, dan Gross Domestic Product (GDP) secara bersama - sama berpengaruh signifikan terhadap Return On Asset (ROE).

Koefisien estimasi dari tiga variabel independen signifikan secara statistik pada tingkat 5 persen dalam kasus risiko likuiditas (FDR) dan 10 persen dalam kasus risiko operasional terhadap ROE. Temuan ini konsisten dengan Wasiuzzaman dan Gunasegavan (2013), Pupik (2012), Hasan et al (2015), dan Tyas Rafelia dan Moh. Didik Ardiyanto (2013).

\section{Kesimpulan}

Penelitian ini bertujuan untuk mendapatkan bukti empiris mengenai risiko keuangan (risiko likuiditas, risiko pembiayaan, dan risiko operasional) dan tingkat kesehatan keuangan bank pada perbankan syariah di Indonesia. Penelitian ini menggunakan analisis data panel, jumlah sampel yang digunakan dalam penelitian ini sebanyak 9 bank syariah dari tahun 20102014. Penelitian ini menggunakan variabel independen Financing to Deposit Ratio (FDR), Non Performing Financing (NPF), ATMR untuk risiko operasional; variabel dependen Net Operating Margin (NOM), Return On Asset (ROA), Return On Equity (ROE); serta menggunakan variabel kontrol ukuran bank, inflasi, dan Gross Domestic Product (GDP). Berdasarkan hasil analisis menunjukkan bahwa:

a. Terdapat hubungan negatif antara FDR, NPF, ATMR risiko operasional, Ukuran bank, Inflasi dengan NOM, sedangkan GDP mempunyai hubungan positif dengan NOM.

b. Terdapat hubungan positif antara FDR dengan ROA, sedangkan NPF, ATMR untuk risiko operasional, ukuran bank, inflasi, dan GDP mempunyai hubungan negatif dengan ROA.

c. Terdapat hubungan positif antara FDR, ATMR untuk risiko operasional, Ukuran bank, GDP dengan ROE, sedangkan NPF dan Inflasi mempunyai hubungan negatif dengan ROE.

d. Hasil dari uji F, risiko keuangan (FDR, NPF, dan ATMR untuk risiko operasional) berpengaruh tidak signifikan terhadap tingkat kesehatan keuangan bank (NOM). Risiko keuangan yang dihadapi oleh bank, tidak berpengaruh secara langsung terhadap NOM. Untuk memperoleh pembiayaan yang lancar, bank harus melakukan strategi yang membutuhkan biaya. Untuk itu, pembiayaan yang besar dan lancar belum tentu berdampak langsung terhadap NOM. Ini juga dikarenakan pengelolaan aktiva yang produktif juga berpengaruh terhadap besarnya nilai NOM. 
e. Hasil dari uji F, risiko keuangan (FDR, NPF, dan ATMR untuk risiko operasional) berpengaruh signifikan terhadap tingkat kesehatan bank (ROA). Secara parsial/ hasil dari perhitungan uji t hanya FDR dan NPF yang berpengaruh secara signifikan dengan ROA. Ini menunjukkan bahwa semakin besar risiko likuiditas yang dihadapi oleh bank, maka tingkat kesehatan bank tersebut akan meningkat, dan semakin tinggi risiko pembiayaan yang ada pada sebuah bank, maka akan terjadi penurunan tingkat kesehatan bank tersebut. Sebuah bank dengan pembiayaan yang besar, diharapkan mampu untuk meningkatkan laba dari bank tersebut. Namun bank juga harus hati-hati dalam mengambil keputusan, dikarenakan besarnya pembiayaan yang bermasalah

\section{Daftar Pustaka}

Abuzar M.A. Eljelly Ahmed Abdelgadir Elobeed. 2013. Performance indicators of banks in a total Islamic banking system: the case of Sudan. International Journal of Islamic and Middle Eastern Finance and Management. Vol. 6 Iss 2 pp. $142-$ 155

Ahmad, Salman, et all. 2012. Determinants Of Profitability Of Pakistani Banks: Panel Data Evidence For The Period 2001-2010. Journal of Business Studies Quarterly 2012, Vol. 4, No. 1, pp. 149165

Ambarwati S, A, D. 2010. Manajemen Keuangan Lanjut. Yogyakarta: Graha Ilmu

Andreas, D \& Wanzenried, G. 2010. Determinant Of Bank Profitability Before And During The Crisis: Evidance From Switzerland.

Ariyanto, Taufik, Faktor Penentu Net Interest Margin Perbankan Indonesia, Jurnal Perbanas, Vol.13 no.1 (juni 2011). akan mengakibatkan menurunnya tingkat kesehatan keuangan bank tersebut.

f. Hasil dari uji F, risiko keuangan (FDR, NPF, dan ATMR untuk risiko operasional) berpengaruh signifikan terhadap tingkat kesehatan keuangan bank (ROE). Hasil dari uji t menunjukkan bahwa hanya FDR yang berpengaruh terhadap ROE. Hal ini menunjukkan bahwa semakin tinggi FDR sebuah bank, maka ROE akan meningkat. Bank Indonesia menambahkan bahwa kriteria kinerja dari kesehatan sebuah bank mengacu pada penilaian yang berorientasi pada risiko, materialitas, proporsionalitas, dan signifikansi serta komprehensif dan terstruktur. Untuk itu risiko keuangan sangat berperan penting dalam menentukan tingkat kesehatan keuangan bank syariah.

Astohar dan Andi Setiawan. 2009. Analisis Pengaruh Ukuran (Size), Capital Adequacy Ratio (CAR), pertumbuhan Deposit, Loan to Deposit Ratio (LDR) terhadap Profitabilitas Perbankan Go Public di Indonesia tahun 2002-2005. Vol. No, 2009.

Astutik, Puji. 2015. Pengaruh Tingkat Kesehatan Bank Menurut Risk Based Bank Rating terhadap Kinerja Keuangan (Studi pada Bank Umum Syariah di Indonesia). Tidak dipublikasikan. Jurnal Universitas Brawijaya

Bungin, Burhan. 2005. Metodologi Penelitian Kuantitatif, Edisi 1, Cetakan 1, Jakarta : Kencana.

Burki, A.A. and G.S.K. Niazi .2006. Impact of Financial Reforms on Efficiency of State owned, Private and Foreign Banks in Pakistan. Centre for Management of Economic Research (CMER) working paper No. 06-49, Lahore University of Management Sciences, Lahore, Pakistan.

Damayanti, Pupik. 2012. Analisis Pengaruh Ukuran (Size), Capital Adeuacy Ratio 
(CAR), Pertumbuhan Deposit, Loan To Deposit Ratio (LDR) Terhadap Profitabilitas Perbankan Go Publik Di Indonesia Tahun 2005-2009. Jurnal Ilmu Manajemen dan Akuntansi Terapan.

Fadhlurrahman, Nuha dan Irni Yunita. 2015. Analisis pengaruh CAR, FDR, NPF dan NIM terhadap Perubahan Laba Komprehensif di Bank Syariah periode 2012-2013. Tidak Dipublikasikan.

Ghozali, Imam 2011. Aplikasi Analisis Multivariate dengan IBM SPSS 19 Edisi 5. Universitas Diponegoro, Semarang.

Hasan, A. A \& Nugroho, W. A. 2008. Manajemen Risiko. Http://hendrakholid.net/blog/manajemen

Hasibuan. 2010. Dasar-dasar Perbankan. Jakarta:Bumi Aksara.

Hassan, H. A et all. 2015. Financial Risk And Islamic Bank's Performance In The Gulf Cooperation Council Countries. The International Journal of Business And Finance Research. ISSN. Vol. 9, No. 15. Pp 103-112

Http://www.bi.go.id

Imad Z. Ramadan, Qais A. Kilani, dan Thair A. Kaddumi. 2011. Determinant of Bank Profitability : Evidance From Jordan. International Journal of Academy Research. Vol. 3. No. 4

Javaid, Saira. 2011. Determinant of Bank Profitability in Pakistan : Internal Factor Analysis. Journal of Yasar University. Vol. 23. No. 6. 3794-3804

Junita, Sherty. 2015. Pengaruh KAP, BOPO dan FDR terhadap Net Operating Margin (NOM) Perbankan Syariah di Indonesia Periode 2010-2014. Skripsi.UIN Syarif Hidayatulah. Jakarta

Manurung, Adler Hayman, dkk., The Determinant of Commercial Banks'Interest Margin in Indonesia: An Analysis of Fixed Panel Regression, International Jurnal of Economics and Financial Issues, Vol. 4, No.2, (2014).

Muhammad Akhtar, Khizer Ali, dan Sharma Sadaqat. 2011. Factors Influencing the Profitability of Islamic Banks of Pakistan. International Academy
Research Journal of Economic and Finance. Vol. 6 1450-2887.

Muhimah. 2010. Pengaruh Dana Pihak Ketiga (DPK), Capital Adequacy Ratio (CAR), Non Performing Financing (NPF) Terhadap Jumlah Penyaluran Pembiayaan pada Bank Muamalat Indonesia. Tidak Diterbitkan.

Neny Erawati dan Richard Llewelyn. 2008. Analisis Pergerakan Suku Bunga dan Laju Ekspektasi Inflasi Untuk Menentukan Kebijakan Moneter di Indonesia.Tidak dipublikasikan. Universitas Kristen Petra,Surabaya.

Peraturan Bank Indonesia No. 13/ 23/ PBI/ 2011. Tentang Penerapan Manajemen Risiko Bagi Bank Umum Syariah Dan Unit Usaha Syariah. Jakarta

Ponco, B. 2008. Analisis Pengaruh CAR, NPL, BOPO, NIM dan LDR terhadap ROA. Tesis Program Pasca Sarjana Magister Manajemen, Universitas Diponegoro.

Puspitasari, Elisa. 2014. Analisis Faktor-Faktor Yang Mempenganuhi Net Interest Margin pada Bank-Bank Umum Di Indonesia. Jurnal Ilmu Manajemen. Vol. 2 No. 14

Rafelia, Thyas danArdiyanto, Moh. Didik. 2013. Pengaruh CAR, FDR, NPF, dan BOPO terhadap ROE Bank Syariah Mandiri Periode Desember 2008-Agustus 2012. Jurnal Akuntansi UNDIP. Vol. 1 : $1-9$.

Rahayu, Bakti Sri. 2014. Pengaruh CAR, NPF, NIM, FDR, dan Pengungkapan CSR terhadap ROA pada perbankan umum syariah di Indonesia tahun 20082012. Tesis Pasca Sarjana Magister Manajemen. UNS

Romdayanah. 2011. Pengaruh Faktor Permodalan, Kualitas Aset, dan Likuiditas terhadap Profitabilitas Bank Umum Syariah. Semarang: Institut Agama Islam Negeri Walisongo

Sanusi,Anwar. 2014. Metodologi Penelitian Bisnis. PT. Salemba Empat : Jakarta.

Satrio,W.E.,dan M.Syaicu. 2013, Analisis Suku Bunga, Inflasi, CAR, BOPO, NPF Terhadap Profitabilitas Bank Syariah. 
Diponegoro. Journal of Management, II (2), pp. 1-10.

Schiniotakis, Nikos Ioani. 2012. Profitability factors and efficiency of Greek banks. Euro Med Journal of Business. Vol. 7 Iss: 2, pp. 185 - 200

Sharma, R. B \& Ravicchandran, K. 2011. Factor That Effect The Profitability Of The Conventional Bank and Sharia Bank In $U A E$.

Sidabalok, Louvti.R dan Viverita.2011. The Determinants of NetInterest Margin in the Indonesian Banking Sector. Working Paper Series, (Online).

Supriyanti, Neni. 2009. Analisis Pengaruh Inflasi dan Suku Bunga BI Terhadap Kinerja Keuangan PT. Bank Mandiri. Universitas Gunadarma.

Suryani. 2011. Analisis Pengaruh Financing to Deposit Ratio (FDR) terhadap Profitabilitas Perbankan Syariah di Indonesia. Vol. 19. No. 1. Hal. 25
Suyono, A. 2005. Analisis Rasio-Rasio Bank yang Berpengaruh Terhadap Return On Asset (ROA). Tesis Program Pasca Sarjana Magister Manajemen, Universitas Diponegoro

Tho'in, Muhammad. 2016. Kompetensi Sumber Daya Bank Syariah Berdasarkan Prinsip-prinsip Syariah Islam (Studi Kasus Pada BNI Syariah di Surakarta). Jurnal Ilmiah Ekonomi Islam, LPPM STIE AAS Surakarta. Vol. 2 No. 3, November 158-171.

Wasiuzzaman, S. Gunasegavan, U.N. (2013) "Comparative study of the performance of Islamic and conventional banks:The case of Malaysia", Humanomics, Vol. 29,( 1), p. 43-60.

Widati, Listyorini Wahyu. 2012. Analisis Pengaruh CAMEL terhadap Kinerja Perusahaan Perbankan yang Go Publik. Jurnal Dinamika Akuntansi, Keuangan dan Perbankan. Nopember, Vol. 1,No.2, hal 105-119 